\title{
The Effect of a Career Group Counseling Program on Career Maturity, Self-esteem and Career Maturity forAgreeable University Students
}

\author{
Moon $\mathrm{Hwa}^{1}$ and Kim Dongwon ${ }^{2 *}$ \\ ${ }^{1}$ Gwangju University \\ $2^{*}$ Dongwon, Assistant Professor of Psychology, Gwangju University \\ ${ }^{1}$ hanback@gwangju.ac.kr, ${ }^{2}$ hanback@gwangju.ac.kr
}

\begin{abstract}
This study aimed at verifying the effect of a career group program for university students with high agreeableness on self-expression, self-esteem and career maturity. To this end, the LCSI personality test was conducted among 160 students in a 4-year university located in $G$ city. And 16 students who wanted to participate in the program among university students with their agreeableness amounting to level 3 (65 or more) were randomly assigned to an experimental group and a control group. The program was conducted toward the experimental group about 120 minutes (per session) for 10 sessions. Independent samples $t$-test was verified by conducting tests of career maturity, self-esteem and self-expression in the form of pretest and posttest. The result of this study showed that the experiment group who participated in the program saw a significant increase in self-expression, career maturity and purpose as well as certainty which are sub-categories of career maturity. The researcher discussed the result, suggestions to career counseling and follow-up studies.
\end{abstract}

Keyword: Agreeableness, Career group counseling program, Expression, Self-esteem

\section{Introduction}

Personality has been regarded as an important variable in searching career. The Big Five personality traits are described as Big Five and are one of representative personality models in understanding the difference of individual's personality[1]. The five factors have been defined as neuroticism, extraversion, openness to experience, agreeableness (friendly), and, conscientiousness. The Big Five has been generalized in various countries and predicted many significant life results including career choice, satisfaction, vocational achievements and success [3].

With regard to studies between the Big Five and career, while openness and conscientiousness are related to career maturity, they are not related to acceptability (friendly) [2].

Agreeableness doesn't show significant correlations with career decision level and career preparation behavior. It shows negative correlations with career search efficacy. In a study with career attitude maturity, an overall score doesn't show significant correlations with sub-categories such as decisiveness, purpose and independence. And it

1 This paper is part of the dissertation of Master's degree from Gwangju University.

Article history:

Received (May 4, 2018), Review Result (August 17, 2018), Accepted (October 22, 2018) 
shows negative correlations with certainty[3]. This testifies that agreeable people are more likely to suffer from difficulties in an area of career attitude maturity, career decision level, career search efficacy and career preparation behavior. However, university students with high agreeableness didn't get the attention in a career group counseling program.

Highly agreeable students tend to show low career maturity and are highly unlikely to decide their career paths. They feel anxiety as well as are shy of strangers and are reluctant to search career paths by meeting others and then their information from others would not be enough. They are also slow to reflect and react. They tend to be engaged with familiar and emotional relations and then have difficulties in task-oriented environments or competitive career search [4][3]. In other words, university students are required to prepare for a career tailored to their courses and values. While they need to find their career paths on their own, their capability to choose a career would not be high due to their lack of career maturity.

As a career-related program in consideration of acceptable university students is very uncommon, it is very essential to offer the program in enhancing expression abilities, self-esteem and career maturity for the agreeable students in the university.

In a situation where a protracted unemployment crisis and youth unemployment increase, university students are required to find a job in the process of searching career paths from a realistic and specific perspective[3]. At this time, career maturity needs to be a precedent trait.

The preceding studies showed that higher levels of career maturity led to a better decision in career paths and have higher correlations with self-growth[3][6] . Higher career maturity contributes to higher academic self-efficacy[7]. Furthermore, it was reported that maturity in career attitudes contributes to career values in pursuing inner values[8].

So, self-esteem, the necessary attitude in dealing with essential issues, is a very important factor. Self-esteem is about positive assessment and attitudes to look oneself as being meaningful, successful, desirable and valuable [9]. In other words, people respecting themselves put energy into valuable things in their lives. University students with high self-esteem are more stable and engaged with social relations and surrounding environments. They can accept others and achieve their goals thanks to self-confidence and a sense of accomplishment and then lead a meaningful life. Self-esteem has a positive effect on the development of career maturity [10]. Therefore, as enhancing self-esteem highly affects their career paths and employment, it is required to develop a career program in improving self-esteem.

Career paths are about expressing themselves to the world. Self-expression is a combination of individual behaviors revealing to interpersonal relations. It is also about expressing oneself in a direct, decisive and candid way while respecting other's emotion, attitudes, hopes, opinions or rights when expressing their feelings and opinions [11]. Previous studies targeted general university students rather than a tailored group counseling program in consideration of traits among specific groups. The limit of these studies lies in the fact that introvert and passive students are more likely to not to express themselves and listen to other's opinions compared with outgoing, social and assertive students. Therefore, the experimental behavior which is the advantage of group counseling is lacking and students with low levels of self-expression cannot get a practical help necessary for career paths and employment. It is recommended to develop an efficient and proper program in line with personality traits of each student. 
This study aimed at enhancing self-expression ability, self-esteem and career maturity by establishing a career group program suitable for the personality of agreeableness after selecting highly agreeable university students. This study is composed of students with agreeableness scores 65 or more in LCSI test and it is experimental by developing a program in line with personality traits of highly agreeable university students. The purpose of this study is to find out each result as follows: in case of conducting the course group program among agreeable university students, firstly whether the score of selfexpressions is improved and secondly whether the score of self-esteem is enhanced and thirdly whether the score of course maturity is promoted compared to a control group.

\section{Study method}

\subsection{Study participants}

The LCSI personality test was conducted among 160 university students at five departments in a 4-year university located in $\mathrm{G}$ city. The researcher randomly assigned an experimental group (nine students) and a control group (five students) targeting 16 ones who wanted to participate in a career group program among 42 ones who scored 65 or more regarding the agreeableness. While the experimental group consisted of seven freshmen, one sophomore and one senior, the control group was composed of seven freshmen. When it comes to the gender of participants, the experimental group included one male as well as eight females and the control group had two males and five females. The average age of the experimental group amounted to $18.56(\mathrm{SD}=1.01)$ and the control group was $18.57(\mathrm{SD}=.79)$.

\subsection{Tools}

Career Group Counseling Program A career group counseling program for agreeable university students was to construct with the aim of improving their self-expression ability, self-esteem and career maturity. This program consisted of five steps and 10 sessions as follows: step 1 structure levels, step 2 self-understanding levels, step 3 selfexpression improvement levels, step 4 career maturity improvement levels and step5 finishing levels. The career group counseling program was conducted 10 sessions about two hours once a week.

LCSI Lim Seong-hwan [6] developed Lim's Character Style Inventory (LCSI) which is made up of 149 items. Seven personality traits (challenging spirit, sociability, acceptability, prudence, stability, self-concept and creativity) can be measured with 5point Likert scale format. The reliability of is as follows: challenging spirit.83, sociability.92, acceptability .84, prudence.91 and stability.71. While its stability is relatively low, the overall reliability is high[4].

Self-expression Test. The Rathus Assertive Schedule (RAS) was designed to assess assertive behavior by Rathus (1973) and Cheon Seok-koon (1994) adapted it to Korean circumstances. The researcher adopted it. The RAS is a 30 -item inventory (17 items are inverted) with a five-point scale. The retest reliability of this scale amounts to .78 and the split-half reliability corresponds to .77 and the concurrent validity is .80 (Rathus and Nevid, 1977). With regard to the reliability coefficient of this study, Cronbach's $\alpha$ corresponds to .91.

Self-esteem Test. Rosenberg (1965) developed a self-esteem test and Cheon Byoungjae (1974) adapted it to Korean circumstances. The high score means high self-esteem. 
With regard to the reliability coefficient of this score, Cronbach's $\alpha$ corresponds to 79 . The Cronbach's $\alpha$ of this study amounts to .84 .

Career Maturity Test A career maturity test is about individual's relative standards of performing developmental tasks necessary for a right choice and a reasonable decision before deciding careers. The Career Attitude Maturity Inventor (CAMI) developed by Lee Ki-hak was used to measure the degree of career attitude maturity. The CAMI is composed of 47 items (decisiveness, preparedness, independence, purpose and certainty) with five sub-categories. In terms of the interpretation of the score, the lower total score means immaturity on career attitudes and vice versa. The Cronbach's $\alpha$ of this study is as follows: total score .92 , decisiveness .92 , purpose 77 , certainty .86 , preparedness .82 and independence .85 .

\subsection{Data analysis}

The purpose of this study was to verify the hypothesis defining that a career group program for agreeable university students would improve their self-expression and career maturity. Self-expression test, self-esteem test and career maturity test were adopted for an experimental group and a control group. Cronbach's $\alpha$ was used to verity the reliability of tools. Independent t-test was used to analyze a pretest and a post test of an experimental group and a control group and SPSS 15.0 was used for statistical processing.

\section{Result}

\subsection{Verification of homogeneity among groups}

To verify whether the levels of self-expression, self-esteem, career maturity and each sub-category among agreeable students participating in an experimental group and a control group are homogeneous or not before participating in the program, independent t-test was conducted to the pre-score of each independent variable of experimental and control groups. Then two groups are homogeneity of variance.

\subsection{The effect of self-expressing career group program}

[Table 1] shows the result of an independent t-test regarding post-test scores of each sub factor-of career maturity, self-esteem and expression between two groups among agreeable university students participating in experimental and control groups.

Table 1. The effect of self-expressing career group program

\begin{tabular}{|c|c|c|c|c|c|c|}
\hline scale name & sub-category & group & $\mathrm{N}$ & M & SD & $\mathrm{t}$ \\
\hline \multirow{6}{*}{ career maturity } & \multirow{2}{*}{ purpose } & experimental group & 9 & 32.11 & 4.17 & \multirow{2}{*}{$3.103 *$} \\
\hline & & control group & 7 & 25.71 & 3.99 & \\
\hline & \multirow{2}{*}{ assurance } & experimental group & 9 & 38.00 & 7.07 & \multirow{2}{*}{$2.659 *$} \\
\hline & & control group & 7 & 29.86 & 4.41 & \\
\hline & \multirow{2}{*}{ total score } & experimental group & 9 & 188.78 & 18.41 & \multirow{2}{*}{$3.096^{*}$} \\
\hline & & control group & 7 & 162.43 & 14.62 & \\
\hline \multirow{2}{*}{ self-expressing } & & experimental group & 9 & 104.67 & 20.83 & \multirow{2}{*}{$2.914 *$} \\
\hline & & control group & 7 & 76.57 & 16.60 & \\
\hline
\end{tabular}


With regard to career maturity, an experimental group $(\mathrm{M}=188.78, \mathrm{SD}=18.41)$ and a control group $(\mathrm{M}=162.43, \mathrm{SD}=14.62)$ had a significant difference $(\mathrm{t}=3.096, \mathrm{p}<.05)$. Significant differences were found in purpose and certainty which are sub-categories of career maturity. When it comes to a self-expressing score, as an experimental group and a control group had a significant difference $(\mathrm{t}=2.914, \mathrm{p}<.05)$, the self-expressing score of an experimental group showed a statistically significant increase. Therefore, the career group program for agreeable university students improves their self-expression, career maturity as well as purpose and certainty which are sub-categories of career maturity.

\section{Discussion}

This study aimed to find out the effect of a career group counseling program on career maturity, self-esteem and self-expression among agreeable university students. The result and discussion of this study is as follows: Firstly, the hypothesis that the experiment group participating in a career group counseling program for agreeable students would see an increase in career maturity compared to the control group was supported. This is in line with the previous research[5][6] verifying significant effects on career maturity by conducting a career group counseling program.

Secondly, the hypothesis that an experimental group participating in the group counseling program for agreeable university students would show a significant increase in their self-esteem statistically compared to a control group was rejected. This is different from the previous research [14]which verified the significant effect on selfesteem with the help of a career group program, the proceeding study [15] which reported positive relations between career maturity and self-esteem and the advanced research19] which suggested that self-expression had an effect on self-esteem.

Thirdly, the hypothesis that an experimental group participating in the group counseling program for agreeable university students would show a significant increase in self-expression statistically compared to a control group was supported. This is in line with the previous studies[12] which verified an increase in self-expression by conducting a self-expression program.

Based on this result, participants realized the need for advancing self-expression by understanding agreeableness and then their ability to express themselves went up in the process of opportunities to express themselves on each session. Activity papers and reviews among participants showed that they had thought that others would know opinions and thoughts and felt heavy on their circumstances. However, it was reported that as they started to express their feelings, they felt relieved and realized the situation what kind of circumstances would make them hard to speak. Furthermore, they were encouraged to express themselves after participating in the program. Under these circumstances, it was fair to say that the participant showed a significant increase in selfexpression after participating in the program.

The significance of this study is as follows:

Firstly, from the academic perspective, this study is meaningful to testify the need for developing a tailored career group counseling program toward agreeable university students in career sequences. Existing group counseling studies targeted the general student rather than the tailored program in consideration of the traits of specific groups. It is hard to find the previous studies which considered the personality traits. In particular, there have been no group counseling studies considering agreeableness. 
The Effect of a Career Group Counseling Program on Career Maturity, Self-esteem and Career Maturity for Agreeable University Students

Secondly, from the practical perspective, this study is significant in revealing the need for proceeding a group counseling program after selecting participants in consideration of their personality. This would be useful not only participants who are active in a practical group but also career counselors who counsel clients in career sequences. Previous career group counseling programs didn't consider personalities and then it was ineffective on participants when practitioners counselled them. In particular, it was hard to see any improvement among agreeable participants and then any effect from a career counseling program could not expect. Therefore, in case of applying this program when counseling agreeable university students, it is expected to enjoy more benefits and career counselors can understand clients better.

Against this backdrop, the limit of this study and the suggestion for follow-up studies are as following: only five departments at a 4-year university in $\mathrm{G}$ city participated in this study and most of them were freshmen. So, it is required to be careful in generalizing and interpreting toward whole agreeable university students. Therefore, it is recommended to conduct follow-up studies toward agreeable university students targeting all departments in various regions.

\section{Reference}

[1] T.A. Judge and R. Ilies, "Relationship of personality to performance motivation: A meta-analytic review," Journal of Applied Psychology, vol.87, no.4, pp.797-807, (2002)

[2] S. D. Brown and A. Hirschi, "Personality, career development, and occupational attainment," in s. d. brown and r. w. rent (eds.), career development and counseling: putting theory and research to work, 2nd ed., pp.299328, New York, NY: Wiley, (2013)

[3] D. Kim, "A study on relationship of personality trait, career maturity, career decision level, career search efficacy, and career preparation behavior," The Journal of Rehabilitation Psychology, vol.20, no.3, pp.607-625, (2013)

[4] S. Lim, "A study for the development and validation of the Lim's character style inventory," Master Thesis in Graduate School of Yeungnam University, (2003)

[5] G. Choi and Y. Lee, "(The) effects of career exploration group counselling on the career maturity of high school students," Master Thesis in Chonnam National University Graduate School of Education, (2012)

[6] G. Kim and H. Kwon, "The effect of LCSI (Lim's Character Style Inventory) career counseling program for meister high school students on their career maturity and self-esteem," The Journal of humanities, Number of Published Articles, pp.375-398, (2012)

[7] B. Ko, "Moderator effect of academic self-efficacy in relationship between career barriers and carrier consciousness maturity recognized by middle school students," Master Thesis in Ajou University, (2011)

[8] V. G. Zunker, "Career counseling: Applied concepts of life planning (2nd ed.)," Monterey CA:Brooks and Cole

[9] C. H. Rosenberg, "Self-concept from middle childhood through adolescence," In J. Suls and A. G. Greenwald(eds.) Psychology perspectives on the self, Hillsadale, N.J.; Erldaum

[10] E. Choi, "Mediation effects of self-esteem in the relationship between body esteem and career maturity of elementary school students," Master thesis in Gyeongin national university of education, (2014)

[11] R. E. Alberti and M. L. Emmons, "Your perfect right: a guide to assertive living (7tb ed)," Sanluis Obispo, CA: Impact Publishers

[12] W. S. So, “A qualitative study of college students' change experiences of self-assertiveness improvement group counseling," Korea Journal of Counseling, vol.9, no.4, pp.1641-1663, (2008)

[13] S. Lim, "Lim's Character Style Inventory," (2015) 
[14] S. Shin and Y. Lee, "The effect of a career training program based on multiple intelligence theory on selfesteem and career self-efficacy among children with underachievement," Master Thesis in Graduate School of Yeungnam University, (2013)

[15] H. Bae and H. Oh, "The relationship among self-esteem, career maturity, and the perceived communication styles of the teachers: the mediating role of the Self Esteem," Master Thesis in the Graduate School of Education Hanshin University, (2016) 
The Effect of a Career Group Counseling Program on Career Maturity, Self-esteem and Career Maturity for Agreeable University Students

This page is empty by intention. 